\title{
The Beginnings of the Graeco-Syro-Arabic Melkite Translation Movement in Antioch
}

\author{
Alexander Treiger \\ Associate Professor, Dalhousie University, Halifax, NS Canada \\ atreiger@dal.ca
}

\begin{abstract}
The present article surveys the early stages of the Graeco-Syro-Arabic Melkite translation movement in Antioch, from the first known translation (the Graeco-Syriac version of the Life of St. Symeon the Stylite the Younger, $B H G$ 1689) dating to $827 / 8$ AD to the Antiochene translators Ibrāhīm the protospatharios, Gregory of Dafnūnā, Chariton of Aršāyā, and Yūḥannā 'Abd al-Masīḥ (the compiler of the Antiochene Menologion), all of them disciples of the martyred patriarch of Antioch Christopher (d.967). It provides new evidence on each of these translators. Significantly, it re-dates Yūhannā 'Abd al-Masīh to the early eleventh century.
\end{abstract}

\section{Keywords}

translations - Greek into Syriac - Syriac into Arabic - Greek into Arabic - Antioch Black Mountain - Christian Arabic literature

In two of his letters written in Syriac, the Catholicos of the Church of the East Timothy I (r. 78o-823) makes reference to his Melkite counterpart Job, patriarch of Antioch (r. ca. 799-ca. 838). ${ }^{1}$ In Letter 43 (written in 782/3, before Job became patriarch) Timothy writes:

Job the Chalcedonian told me that he has seen a small (number) of scholia on [Aristotle's Topics], but only, he said, on certain chapters. ${ }^{2}$

1 On patriarch Job of Antioch's dates, see Klaus-Peter Todt and Bernd Andreas Vest, Syria (Syria Prōtē, Syria Deutera, Syria Euphratēsia), 3 vols., Vienna: Österreichische Akademie der Wissenschaften, 2015, vol. 1, p. 336.

2 Sebastian P. Brock, "Two Letters of the Patriarch Timothy from the Late Eighth Century on 


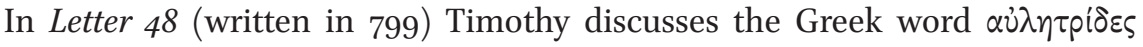
("flute-girls"), which appears in Aristotle's Analytica Posteriora (A.13, 78b3o-31). He comments that this word

is a strange one and unusual, even in Greek, as I believe. For when we were translating the Book of [Aristotle's Topics] into Arabic from Syriac, we had with us some Greeks (yawnāyē), and one of them was the Patriarch of the Melkites (patriyarkā d-malkāyēe [=Job of Antioch]; only with difficulty could they understand the word. ${ }^{3}$

Evidently, Timothy regards Job of Antioch as an authority in Greek, though he cannot help but comment - not without some cultural triumphalism - that, when it comes to understanding Aristotle, Syriac-speakers like himself are often better equipped than the Greeks, because they have at their disposal prior Syriac translations of Aristotle's works.

Perhaps not coincidentally, it is approximately at the time of Job of Antioch that the Melkite Antiochenes, too, became involved in translations, though largely of ecclesiastical rather than philosophical nature. ${ }^{4}$ The very first Melkite translation from Antioch known to us is the Syriac version of the Life of St. Symeon the Stylite the Younger (BHG 1689). As we learn from the concluding note of the unicum manuscript of this text (Sinai syr. $\mathrm{M}_{5} \mathrm{~N}+\mathrm{M} 76 \mathrm{~N}$ ), this translation was produced by a certain Theodosius of Sarmin at the Monastery of St. Symeon the Stylite the Younger on the Black Mountain - an important intellectual centre located some $29 \mathrm{~km}$ southwest of Antioch ${ }^{5}$ - in the year 1139

Translations from Greek," Arabic Sciences and Philosophy 9 (1999): 233-246, p. 236; commentary, p. 242. Cf. Martin Heimgartner, Die Briefe 42-58 des ostsyrischen Patriarchen Timotheos I, 2 vols., CSCO 644-645 / Scriptores Syri 248-249, Louvain, Peeters, 2012, Syriac text: vol. 1, p. 67 / German trans.: vol. 2, p. 50 (section 43,7).

3 Brock, “Two Letters," p. 239; commentary, p. 246. Cf. Heimgartner, Die Briefe, Syriac text: vol. 1, p. 92 / German trans.: vol. 2, p. 77 (section 48,10). Incidentally, this is the earliest attestation of the term "Melkites."

4 Job of Antioch is also the author of the first Arabic Christian homily that we know about - an unfortunately no longer extant sermon on the Feast of the Cross. See Michel van Esbroeck, "Un recueil prémétaphrastique arabe du XI ${ }^{\mathrm{e}}$ siècle (British Museum Add. 26.117 et Or. 5019)," AB 85 (1967): 143-164, at p. 147; Joseph-Marie Sauget, "L'homéliaire arabe de la Bibliothèque Ambrosienne (X.198 Sup.) et ses membra disiecta," AB 88 (1970): 391-474, at pp. 415, 420; Joseph Nasrallah with Rachid Haddad, Histoire du mouvement littéraire dans l'église melchite du ve au $X X^{e}$ siècle, 5 vols. in 8 parts, Louvain: Peeters, 1979-2017, vol. II.2, pp. 34-35.

5 On this monastery (known in Turkish as "Aziz Simon Manastırı"), now lying in ruins, see Jacqueline Lafontaine-Dosogne and Bernard Orgels, Itinéraires archéologiques dans la région d'Antioche: Recherches sur le monastère et sur l'iconographie de S. Syméon le Jeune, Brussels: 
of the Seleucid era $(=827 / 8 \mathrm{AD})$, during the days of the "holy Mar Job, patriarch of the city of God Antioch," at the exhortation (ba-hpit tút $\underline{t} \bar{a})$ of the abbot of that monastery Abba Nicetas $(A \underline{b} \bar{a} \text { Niqqütā })^{6}$

As compared to Timothy's (and his associate Abū Nūḥ al-Anbārī's) Syro-Arabic translation of Aristotle's Topics, ${ }^{7}$ Theodosius of Sarmin's Graeco-Syriac version of the Life of St. Symeon the Stylite the Younger was a relatively modest affair. It did not have the kind of caliphal support that the Syro-Arabic translation of the Topics enjoyed and was not intended for Muslim audience. Rather, it was meant to serve the internal needs of Theodosius' Melkite Christian community, most immediately those of his own monastery, of which St. Symeon the Stylite the Younger was the patron saint. The Syriac version of the Life was likely produced to be read publicly during the monastery's annual celebration of its patron saint, which took place on May 24, though it was surely also intended for Syriac-speaking monks' private reading.

Nonetheless, the Graeco-Syriac translation of the Life of St. Symeon the Stylite the Younger is significant in that it is the symbolic beginning of what was to become a highly influential undertaking - the mass production of translations of Christian literature in Antioch and the surrounding monasteries during the period of Byzantine rule (969-1084). I shall therefore offer brief comments regarding this text.

The Syriac Translation of the Life of St. Symeon the Stylite the Younger

The Translator Theodosius of Sarmin and the Commissioner Abba Nicetas $(827 / 8$ AD)

Though Theodosius of Sarmin is otherwise unknown, it can be pointed out that Sarmin is a town in the vicinity of Idlib, some 6o km southeast of Antioch and some $50 \mathrm{~km}$ southwest of Aleppo. This area must have been largely Syriacspeaking in the early ninth century (the Arabicization rate there must have

Éditions de Byzantion, 1967; Mariusz Gwiazda, "Le Sanctuaire de Saint-Syméon-Stylite-leJeune au Mont Admirable à la lumière de la documentation photographique du père Jean Mécérian," Mélanges de l'Université Saint-Joseph 65 (2013-2014): 317-340.

6 Sinai syr. M15N, fols. 1r and $119 \mathrm{r}$ and M76N, fol. 8, as cited by Philothée du Sinaï, Nouveaux manuscrits syriaques du Sinaï, Athens: Fondation du Mont Sinaï, 20o8, pp. 320-322 and 592593; on this manuscript, see also Paul Géhin, Les manuscrits syriaques de parchemin du Sinaï et leurs membra disjecta, Louvain: Peeters, 2017, p. 184.

7 On this subject, see Dimitri Gutas, Greek Thought, Arabic Culture: The Graeco-Arabic Translation Movement in Baghdad and Early 'Abbāsid Society (2nd-4th/8th-1oth Centuries), London and New York: Routledge, 1998, pp. 61-69. 
been quite slow). As many of the monks on the Black Mountain would have come from precisely this hinterland region between Antioch and Aleppo, they too would have been Syriac-speakers (in contrast to the then still predominantly Greek-speaking Antioch). It is therefore not surprising that translations from Greek into Syriac were being carried out at this location.

In contrast to Theodosius of Sarmin, the abbot of the Monastery of St. Symeon Abba Nicetas happens to be attested - so I believe - in a contemporary source. This is the short Arabic treatise Miracles of St. Eustratius. ${ }^{8}$ Section 4 of this text is a very important source on the process of election of bishops in the patriarchate of Antioch during Job of Antioch's tenure as patriarch. It reads as follows:

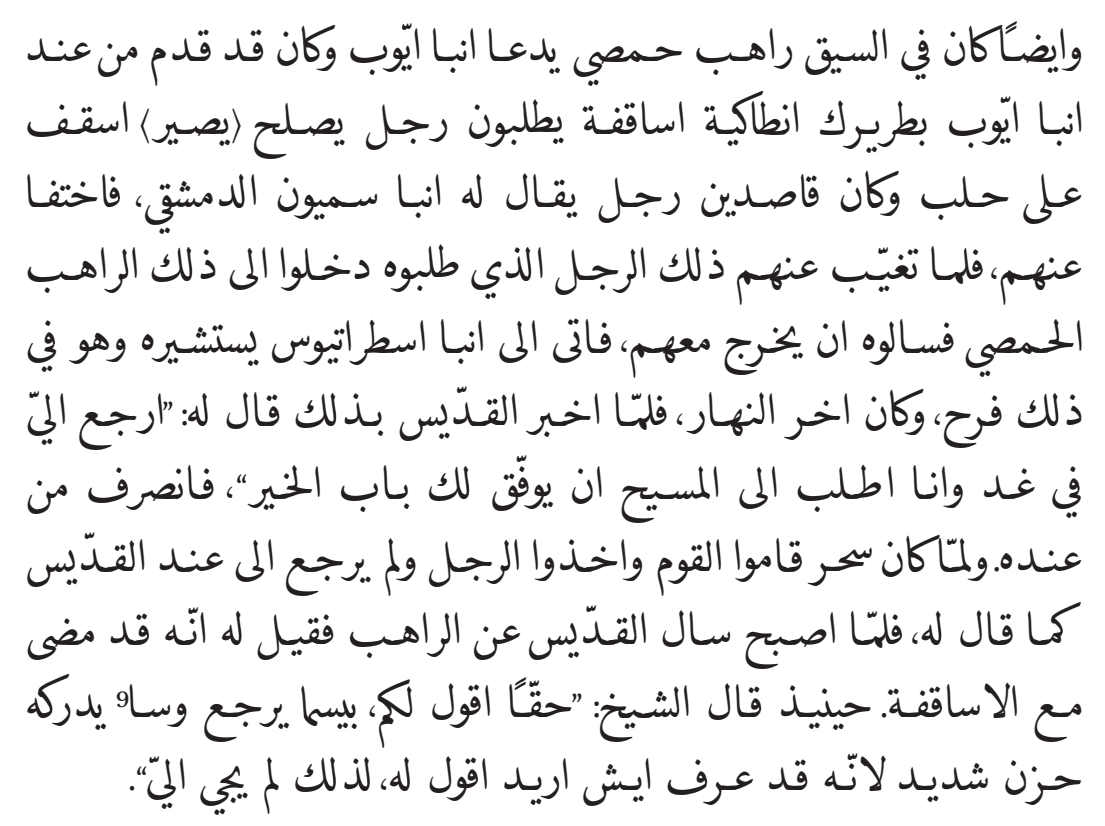

8 Alexander Treiger, "Unpublished Texts from the Arab Orthodox Tradition (2): Miracles of St. Eustratius of Mar Saba (written ca. 86o)," Chronos 33 (2016): 7-20. Though this article erroneously identifies St. Eustratius' residence as Mar Saba, in reality he was a monk at Mar Chariton; this mistake has been corrected in Alexander Treiger, "Unpublished Texts from the Arab Orthodox Tradition (3): The Paterikon of the Palestinian Lavra of Mar Chariton," Chronos 38 (2018): 7-46.

9 Here and below, $s \bar{a}($ mark is a future marker in Christian Palestinian Arabic of the first millennium - see Joshua Blau, A Grammar of Christian Arabic, Based Mainly on South-Palestinian Texts from the First Millennium, 3 vols., Louvain: Secrétariat du csco, 1966-1967, vol. 1, pp. 68-69, §8.1. 


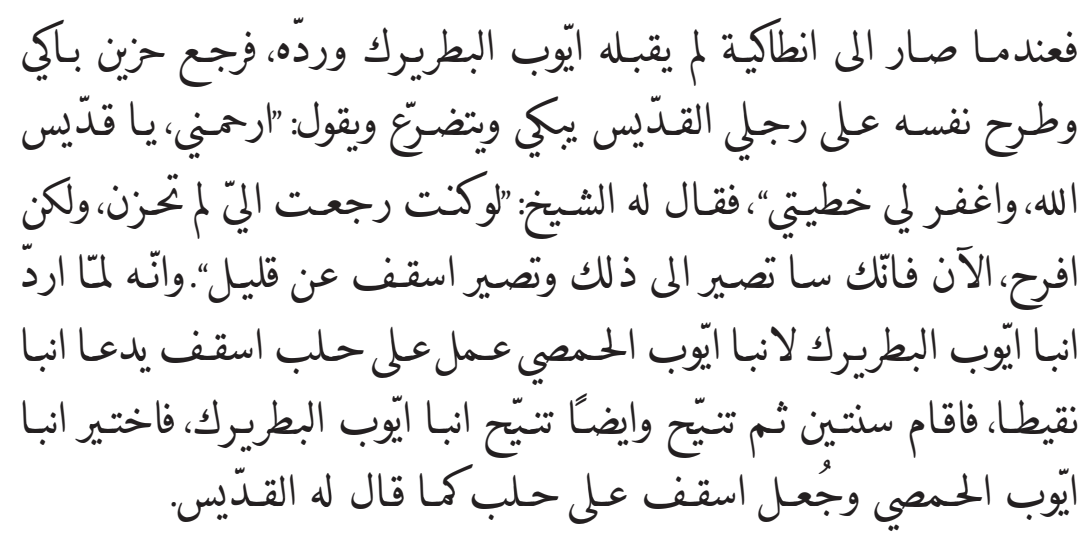

There was at the Lavra [of Mar Chariton in Palestine] another monk from Hims, whose name was Abba Job. At that time, bishops came from Patriarch Job of Antioch to find someone who could be fit to become bishop of Aleppo. They sought a certain man called Abba Symeon from Damascus, but he hid himself from them. As they could not find the man they sought, they approached this monk from Hims and asked him to go with them. He came to Abba Eustratius to seek his council, rejoicing at the news. This was the end of the day. When he told the saint about this, the saint said: "Come back to me tomorrow, and I will pray to Christ to direct you to the gate of the good." The monk departed from his presence. At dawn, those people [i.e., the bishops] came and took the man with them, and he never came back to the saint, as the saint had bidden him to do. When it was morning, the saint inquired about that monk and was told that he had left with the bishops. The elder then said: "Verily I say to you, he will have a wretched return and will be overcome with great sorrow. He knew what I was going to say to him; this is why he never came back to me."

When [Abba Job from Hims ] came to Antioch, Patriarch Job did not accept him and sent him back. He came back weeping and overcome with sorrow. He then cast himself at the saint's feet, crying and beseeching him, saying: "O saint of God, have mercy on me and forgive me my sin." The elder said to him: "If you had come back to me, you would not have had to grieve. Now, however, rejoice, for you will obtain this and will become a bishop soon." Indeed, when Patriarch Job rejected Abba Job from Himș, he appointed a bishop over Aleppo whose name was Abba Nicetas (Anbā Niqūtā $)$. He remained [bishop] for two years and then died. Patriarch Job also died, and Abba Job from Hims was chosen and ordained to be bishop of Aleppo, as the saint had predicted. 
It seems very likely that the Abba Nicetas who was appointed bishop of Aleppo by patriarch Job of Antioch sometime in the mid-83os, ${ }^{10}$ according to the Miracles of St. Eustratius, is the same person as the Abba Nicetas who was the abbot of the Monastery of St. Symeon on the Black Mountain in 827/8 AD. It would have been, after all, quite natural for the patriarch of Antioch to elect the abbot of a major monastery in the vicinity of the city to the episcopal see of Aleppo, though as the Miracles of St. Eustratius testifies, prior to this appointment an extensive search had been conducted, for reasons unknown to us, among Syrian monks at the Lavra of Mar Chariton in Palestine.

1.2

The Copyist Abraham, Disciple of Abba Serapion (932/3 AD)

We shall now consider the manuscript in which the Syriac version of the Life of St. Symeon the Stylite the Younger is preserved. As mentioned above, this is $\mathrm{Si}-$ nai syr. $\mathrm{M}_{15} \mathrm{~N}+\mathrm{M}_{7} 6 \mathrm{~N}$, which dates to 932/3 AD. Here, too, the context is crucial. The colophon says:

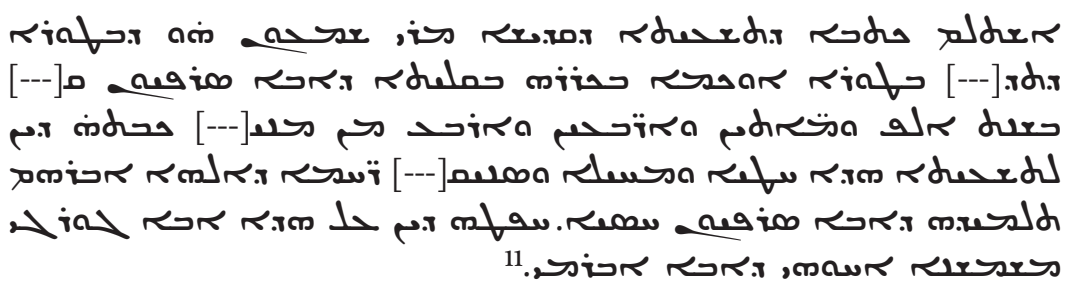

The book of the story of Saint Mar Symeon, the one on the Won[drous] Mountain, on the Black Mountain in KRRH in the cell of [the holy?] Abba Serapion was completed in the year 1244 according to the reck[oning of Alexander / the Greeks, i.e., the Seleucid era $=932 / 3 \mathrm{AD}]$. This story was copied by the weak sinner in need of God's mercy, Abraham, disciple of the venerable Abba Serapion. He was commissioned to do so by Abba George the deacon, the brother of Abba Abrami.

As we learn from the colophon, the copyist is a certain "Abraham, disciple of the venerable Abba Serapion." The copying took place on the Wondrous Mountain / Black Mountain (both names are indicated, albeit the former - in Syriac: Tuura $\bar{d}$-tededmūrta - is truncated due to the partial loss of the left margin) in a

10 According to the text, Abba Nicetas' tenure as bishop of Aleppo was very brief: only two years. After that he died, and patriarch Job died soon thereafter. As the presumed death date of patriarch Job of Antioch is $838 \mathrm{AD}$, this must have happened in the mid-83os.

11 Sinai syr. M15N, fol. $119 \mathrm{r}$ - see Philothée, Nouveaux manuscrits syriaques, p. 320 (Plate) and pp. 321-322 (partial transcription); cf. p. 593 . 
place called KRRH (presumably, $\chi \hat{\omega} p \alpha)^{12}$ in the cell (qellāytā) of Abba Serapion. The commissioner of the copy is named as Abba George the deacon, the brother of Abba Abrami ("Abrami" must be an alias of the copyist, named above as Abraham).

As chance has it, Abraham and Serapion are attested in yet another source, the Arabic colophon of a lost tenth-century manuscript of John Climacus' Book of the Ladder, fortunately reproduced verbatim by a twelfth-century copyist:

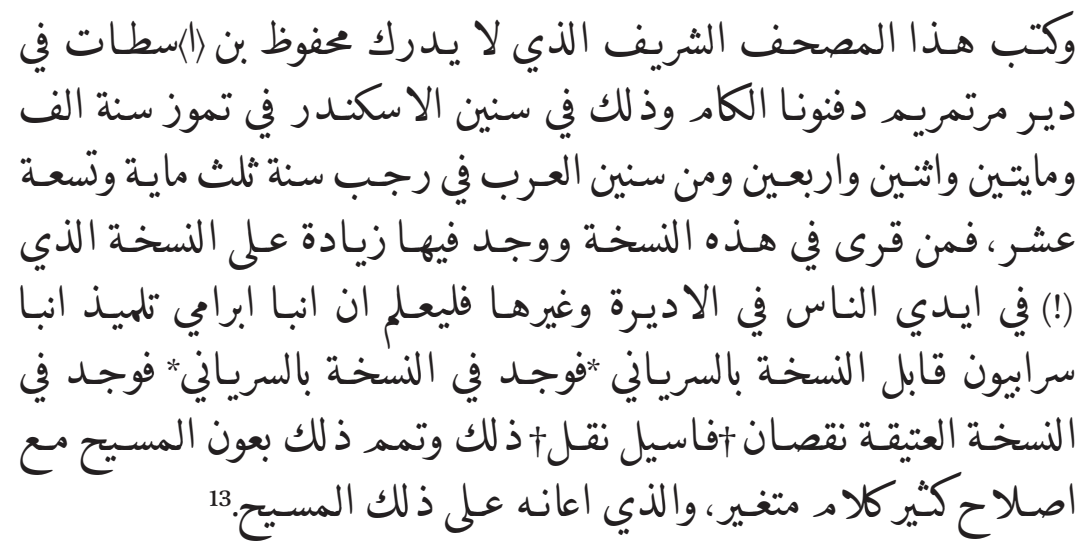

Maḥūz ibn <U>sțāt copied this noble and profound codex at the Monastery of Our Lady Mary (Mart Maryam) Dafnūnā [on] the Black [Mountain] $(a l-L u k k \bar{a} m)^{14}$ in July 1242 according to the era of Alexander [i.e., the

The Syriac term حمورة (both of them transliterations of the Greek $\chi \hat{\omega} \rho \alpha$ ) are attested in several descriptions of the location of the Monastery of the Theotokos Dafnūnā - see Joseph-Marie Sauget, Premières recherches sur l'origine et les caractéristiques des synaxaires melkites (XI ${ }^{e-X V I I}{ }^{e}$ siècles), Brussels: Société

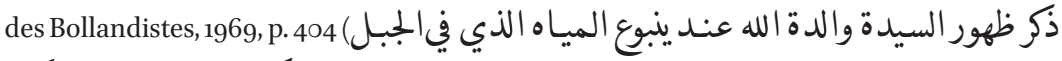

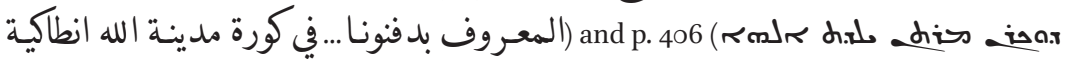
ה.

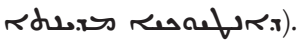

13 Saint Petersburg, Institute of Oriental Manuscripts, B1217 (year 1178), fol. 222r, as cited in Serikoff, Descriptive Catalogue, B1217. On this manuscript see Alexander Treiger, "Christian Graeco-Arabica: Prolegomena to a History of the Arabic Translations of the Greek Church Fathers," Intellectual History of the Islamicate World 3 (2015): 188-227; Serge A. Frantsouzoff, "Le phénomène des feuillets transposés dans les manuscrits arabes chrétiens de St. Pétersbourg," in: Actes du Symposium International "Le Livre. La Roumanie. L'Europe" (Bibliothèque Métropolitaine de Bucarest, 4ème édition, 20-23 septembre 2011), vol. 3, Bucharest: Biblioteca Bucureștilor, 2012, pp. 210-22o.

From the Syriac ukkāmā, "black." 
Seleucid era], or Rağab 319 according to the era of the Arabs [=20-31 July $931 \mathrm{AD}] .{ }^{15}$ Whoever reads this copy and finds that it has an addition (ziya a da) in comparison to [other] copies in people's possession in monasteries and elsewhere, let him know that Abba Abrami, disciple of Abba Serapion, has collated this copy with the Syriac ${ }^{16}$ and discovered that the old copy had a gap (nuqșān), so he had [the missing part] translated ${ }^{17}$ and completed with Christ's help, amending also many words that were at variance [with the Syriac]. Christ helped him to accomplish this.

From this colophon, we learn, first, the exact location of the monks Abraham (or Abrami) and Serapion: the Monastery of the Theotokos at Dafnūnā (ancient Daphne, present-day Harbiye south of Antioch), not too far from the Monastery of St. Symeon. More importantly, we learn that the same Abraham was himself involved in translations. He apparently took the old Arabic translation of John Climacus' Book of the Ladder ${ }^{18}$ - produced, in all likelihood, in Palestine or at Sinai in the ninth century - and collated it with the Syriac translation of the same book. ${ }^{19}$ It turned out that the Arabic version had a lacuna, which he then completed (or asked someone to complete) based on the Syriac version. He also modified the Arabic translation based on the Syriac text.

This is precious evidence of Syro-Arabic translation activity in Antioch prior to the Byzantine re-conquest. Apparently, as compared to the first half of the ninth century, a century later - by the first half of the tenth century - Arabic had already become a significant language in the Melkite monasteries in the vicinity of Antioch. Arabic-speaking Christians, like the aforementioned copyist Maḥfūz ibn Usțāt, must have co-existed with Syriac-speakers such as

$15 \quad$ Rağab $319 \mathrm{AH}$ began on 20 July $931 \mathrm{AD}$.

16 Disregarding fa-wağada fì l-nusha bi-l-suryānī (the copyist intended to write fa-wağada $f \grave{\imath}$ l-nusha al-'atīqa, but made a mistake the first time; he then copied it again).

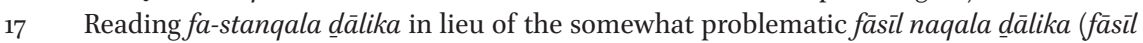
could conceivably mean "Basil," but this spelling of the name is rather uncommon, though see Fāsiliyūs in Saint Petersburg, Institute of Oriental Manuscripts A993, fol. 3ov).

Sinai ar. 329 (1oth cent.), fols. 1r-132r; Sinai ar. 330 (1oth cent.), fols. 1r-176v; Sinai ar. $33^{2}$ (1oth cent.), fols. 1r-132r; Sinai ar. NF Perg. 49 (1oth cent.); Sinai gr. 1922 (which in reality is an Arabic manuscript!), fols. 4v-21r (the first four mayāmir); and many others.

The Syriac translation of the Book of the Ladder is still unpublished. It is preserved in three manuscripts: Sinai syr. 56 (8th or early 9th cent.; cf. Géhin, Les manuscrits syriaques, p. 108); the upper writing of the "Codex Climaci Rescriptus" (formerly, in Agnes Smith Lewis' possession, then kept at Westminster College in Cambridge, in 2010 purchased by The Green Collection; cf. Géhin, Les manuscrits syriaques, pp. 126-127); and Leiden Or. 4795 [olim Or. 2346] (13th cent.). See Herman Teule, "L'Échelle du Paradis de Jean Climaque dans la tradition syriaque: premières investigations," Parole de l'Orient 20 (1995): 279-293. 
Abraham (or Abrami), though, to be sure, the latter was fluent in Arabic as well. Translations of Christian literature into Arabic, most of which were produced in the multilingual monastic communities of Palestine (notably Mar Saba), as well as at Sinai, had been making their way to Antioch. Antiochene monks were not, however, simply passive recipients of these translations. We learn that they took care to revise some of them. Significantly, in the case of John Climacus' Book of the Ladder, the revision did not take place on the basis of the Greek original (it is unlikely that Abraham knew Greek), but on the basis of the Syriac version, itself translation from Greek.

\section{Antiochene Translations after the Byzantine Re-Conquest: The Disciples of the Patriarch Christopher}

After the Byzantine re-conquest of Antioch in 969, knowledge of Greek became again more common. A new wave of translations from Greek into Arabic (and to a lesser extent into Syriac) and from Syriac into Arabic takes place in Antioch and the surrounding monasteries. ${ }^{20}$ It is noteworthy that several of the earliest translators are disciples of the martyred patriarch of Antioch Christopher (d. 967). These are (1) Ibrāhīm the protospatharios, a translator from Greek into Arabic (who also wrote the famous Life of Christopher); (2) Gregory, abbot of the Monastery of the Theotokos Dafnūnā, a translator from Syriac into Arabic; and, possibly, (3) Chariton, abbot of the Monastery of the

20 Additionally, translations into Georgian were carried out. The most significant Georgian translator active in Antioch is Eprem Mtsire (Ephrem the Lesser, d. ca. 1101). See Michael Tarchnišvili, Geschichte der kirchlichen georgischen Literatur, Vatican: Biblioteca Apostolica Vaticana, 1955, pp. 182-198; Maia Raphava and Bernard Coulie, "Les colophons d'Éphrem Mtsire et les traductions géorgiennes de Grégoire de Nazianze," Le Muséon 104 (1991): 109-124; Nino Doborjginidze, "Zur textkritischen Methode georgischer Übersetzer aus Antiochia: Die Problematik von Einleitung, Text und Textempfänger," Le Muséon 124.3-4 (2011):357-370. On Georgian presence in the region, see also Wachtang Z. Djobadze, Materials for the Study of Georgian Monasteries in the Western Environs of Antioch on the Orontes, Louvain: Corpus Scriptorum Christianorum Orientalium, 1976; Wachtang Djobadze, "Georgians in Antioch on-the-Orontes and the Monastery of St. Barlaam," in: Werner Seibt (ed.), Die Christianisierung des Kaukasus. The Christianization of Caucasus (Armenia, Georgia, Albania), Referate des Internationalen Symposions (Wien, 9. bis 12. Dezember 1999), Vienna: Österreichische Akademie der Wissenschaften, 2002, pp. 37-53. Armenian presence in the region is also noteworthy. See Jos J.S. Weitenberg, "The Armenian Monasteries in the Black Mountain," in: Krijna N. Ciggaar and David M. Metcalf (eds.), East and West in the Medieval Eastern Mediterranean I: Antioch from the Byzantine Reconquest until the End of the Crusader Principality, Leuven: Peeters, 2006, pp. 79-93 (with some notes on translations into Armenian). 
Theotokos Aršāyā, a translator from Greek into Arabic. I shall devote brief comments to each of them.

\subsection{Ibrähìm the Protospatharios}

Ibrāhīm the protospatharios' translation activity has been masterfully surveyed by Joshua Mugler, who has also studied the reception history of his Life of Christopher. ${ }^{21}$ The list of Ibrāhīm's Graeco-Arabic translations includes the following:

- Basil of Caesarea's Homily on Cheesefare Sunday and the Beginning of the Fast (=Second Homily on Lent, CPG 2846);22

- Pseudo-Dionysius the Areopagite's On Good and Evil (=Divine Names, chapter 4, §§18-35); ${ }^{23}$

- Gregory of Nazianzus' Orations (the Arabic versions of Orations 29, 30, 40, and 43 are securely attributed to Ibrāhīm; others, too, are likely to be his); ${ }^{24}$

- Pseudo-Gregory of Nyssa's Encomium to St. Ephrem (CPG 3193; BHG 583);25

21 Joshua Mugler, "Ibrāhīm ibn Yūḥannā and the Translation Projects of Byzantine Antioch," in: Barbara Roggema and Alexander Treiger (eds.), Patristic Literature in Arabic Translations, Leiden: Brill, 2020, pp. 180-197; Joshua Mugler, "A Martyr with Too Many Causes: Christopher of Antioch (d. 967) and Local Collective Memory," PhD dissertation, Georgetown University, 2019. On the title "protospatharios," see Rodolphe Guilland, "Études sur l'histoire administrative de l'empire byzantin: Les titres auliques des eunuques: Le protospathaire," Byzantion 25-27.2 (1955-1957): 649-695; reprint: Rodolphe Guilland, Recherches sur les institutions byzantines, 2 vols., Berlin: Akademie-Verlag, 1967, vol. 2, pp. 99-131.

22 Saint Petersburg, Institute of Oriental Manuscripts A509, fols. 19r-24v; Balamand 125, fols. 159v-167v. Another manuscript can now be added: Paris, BnF ar. 133, fols. 201r-209r (the manuscript contains a rich selection of Basil's homilies, including homilies on the Psalms, which deserves a careful study). The Saint Petersburg manuscript is the only one that ascribes the translation to Ibrāhīm the protospatharios.

23 For a list of manuscripts, see Alexander Treiger, "New Evidence on the Arabic Versions of the Corpus Dionysiacum," Le Muséon 118.3-4 (2005): 219-240, at pp. 238-239.

24 Jacques Grand'Henry, "La version arabe du Discours 24 de Grégoire de Nazianze: Édition critique, commentaires et traduction," in Bernard Coulie (ed.), Versiones orientales, repetorium ibericum et studia ad editiones curandas, Turnhout: Brepols, 1988, pp. 197-291; Jacques Grand'Henry, Sancti Gregorii Nazianzeni Opera: Versio arabica antiqua, I: Oratio XXI (arab. 20), Turnhout: Brepols, 1996; Laurence Tuerlinckx, Sancti Gregorii Nazianzeni Opera: Versio arabica antiqua, II: Orationes I, XLV, XLIV (arab. 9, 10, 11), Turnhout: Brepols, 2001; Jacques Grand'Henry, Sancti Gregorii Nazianzeni Opera: Versio arabica antiqua, III: Oratio XL (arab. 4), Turnhout: Brepols, 2005; Jacques Grand'Henry, Sancti Gregorii Nazianzeni Opera: Versio arabica antiqua, IV: Orationes XI, XLI (arab. 8, 12), Turnhout: Brepols, 2013. For additional bibliography, see Barbara Roggema and Alexander Treiger (eds.), $P a$ tristic Literature in Arabic Translations, Leiden: Brill, 2020, pp. 391-393.

25 Louis Cheikho, "Madīh qadīm li-Mār Afrām waḍa'ahu al-qiddīs Ġrìgūriyūs usquf Nīsas," al-Mašriq 19 (1921): 452-459 and 506-516. This encomium is appended to the Arabic 
- John Chrysostom's Homily of Consolation to Those who Mourn (=First Sermon on Patience, CPG 4620);26

- John Chrysostom's homily on the prophet Elijah (=On Sts. Peter and Elijah, CPG 4513); ;7

- Symeon Metaphrastes' encomia to the evangelists Luke (BHG 991) ${ }^{28}$ and John (BHG 919). ${ }^{29}$

In addition to the title "protospatharios," Ibrāhīm is also sometimes referred to as "the imperial secretary" (Ar. al-kātib al-malakì) / "the emperor's secretary" (Syr. kātatoba $\underline{a} \underline{d}-m a l k \bar{a})$. In Arabic, this appellation appears in the captions and concluding notes of several of Ibrāhīm's translations. ${ }^{30}$ In Syriac, it appears in a very important colophon (London, BL Or. 86o7, a membrum disiectum of Sinai syr. 71), which showcases another crucial aspect of Ibrāhīm's translation activity. Here is the most significant section of the colophon:

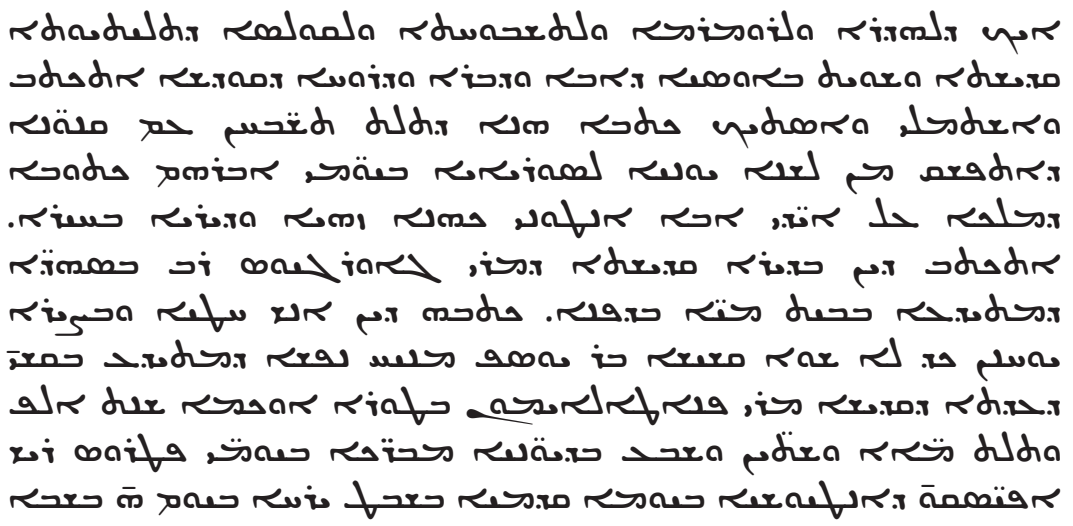

translation of a collection of fifty-two homilies by Ephrem (on which see below). In addition, it is also sometimes preserved separately in manuscripts (e.g., Monastery of St. Macarius, Suppl. 42 = Hag. 79; see Ugo Zanetti, "Supplément à l'inventaire des manuscrits de Saint-Macaire," Bulletin de la Société d'archéologie copte 45 (2006): 153-195, at p. 176). Sinai ar. 282 (year 1278), fols. 18ov-189r; Sinai ar. 439, fol. 223v-243v; Sinai ar. 5 O5 (13th c.), fols. $258 \mathrm{r}-275$ r. To these manuscripts, one can add Sinai ar. 56o, fols. $125 \mathrm{r}-136 \mathrm{r}$.

27 Sinai ar. 407 , fols. $156 \mathrm{v}-168 \mathrm{v}$; Sinai ar. 423 , fols. $578 \mathrm{r}-587 \mathrm{v}$.

28 Sinai ar. 482 , fols. 15 r-22v. For a different Arabic version of the same text, see Sinai ar. 423 (the one-volume abridgment of the Antiochene Menologion), fols. 112v-117r.

29 Sinai ar. 405, fols. 5ov-61v.

$30 \quad$ E.g., at the end of his translation of Pseudo-Gregory of Nyssa's Encomium to St. Ephrem (Paris, BnF ar. 135, fol. 293v cited below; Vat. ar. 463, fol. 184v); at the beginning of his translation of Gregory of Nazianzus' Oration 43 [Encomium to St. Basil] (Sinai ar. 40o, fol. 4v; Sinai ar. 401 , fol. $5 \mathrm{v}$ ); at the beginning of his translation of Pseudo-Dionysius the Areopagite's On Good and Evil (Sinai ar. 85, fol. 62r and other manuscripts). 


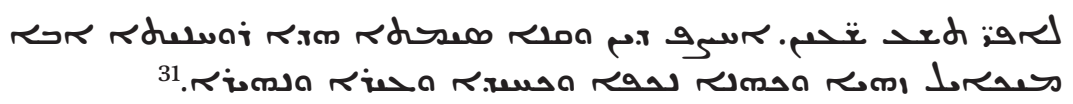

For the honour, exaltation, glory, and praise of the Holy and Consubstantial Trinity, Father, Son, and Holy Spirit, this book of the Three Odes, together with the Canons - which was translated from the Greek language into Syriac in the days of Abraham the emperor's secretary at the hands of Abba Antonios, ${ }^{32}$ the excellent priest and renowned monk - has been copied, accomplished, and brought to an end. It was copied in the holy Monastery of St. George, great among the martyrs, known as "the one in Beth Mayya," [i.e.,] in Daphne. A wretched sinner John, an unworthy priest, known among the priests of the holy Church of St. Panteleimon on the Black Mountain, son of the late Joseph, copied it in the year 1367 of the blessed Greeks [ $=1056$ AD ], in the days of Peter archbishop of Antioch [=patriarch Peter III, r. 1052-1056], on Thursday, February 1, towards the ninth hour. This spiritual treasure was commissioned and purchased by the excellent Abba Michael, the chaste, reverent, industrious, and illustrious priest.

This colophon shows that Ibrāhīm was apparently involved, as a patron, in Graeco-Syriac liturgical translations (in this case, those of the Triodion and the Pentecostarion), which were taking place in the Middle Byzantine period as part of the effort to byzantinize the Syriac Melkite liturgy. ${ }^{33}$ This lends support to the identification, first proposed by Joseph Nasrallah, of Ibrāhīm the

For this manuscript, see Géhin, Les manuscrits syriaques, pp. 118-123 (where the full version of the colophon is reproduced). For a partial English translation, see Sebastian Brock, "Syriac Manuscripts Copied on the Black Mountain, near Antioch," in: Regine Schulz and Manfred Görg (eds.), Lingua Restituta Orientalis: Festgabe für Julius Assfalg, Wiesbaden: Harrassowitz, 199o, pp. 59-67, at p. 62.

32 It is unclear whether this Antonios is identical with the famous Graeco-Arabic translator Antonios, abbot of the Monastery of St. Symeon on the Black Mountain in the first half of the eleventh century, on whom see Habib Ibrahim, "Some Notes on Antonios and His Arabic Translations of John of Damascus," in: Barbara Roggema and Alexander Treiger (eds.), Patristic Literature in Arabic Translations, Leiden: Brill, 2020, pp. 158-179. Though Brock, "Syriac Manuscripts," pp. 66-67 raises this possibility, he does so "with some hesitation," due to the fact that the Graeco-Arabic translator Antonios "is not ... otherwise known to have translated into Syriac." This is echoed by Géhin, Les manuscrits syriaques, p. 121: "l'identification du traducteur [of the Triodion and Pentecostarion], le hiéromoine Antoine, avec l'higoumene Antoine du couvent de Saint-Siméon du Mont Admirable est ... incertaine, car on ne connaît de ce dernier que des traductions du grec à l'arabe dans le domaine patristique."

On Byzantinization, see Daniel Galadza, Liturgy and Byzantinization in Jerusalem, Oxford:

Oxford University Press, 2018. 
protospatharios with a certain "Abramios, protospatharios over the Godguarded [imperial] bedchamber and mystikos," one of the signatories of patriarch Alexios of Constantinople's decree, issued in 1030 and imposing restrictions on Syriac-speaking Jacobite Christians in Melitene. ${ }^{34}$ The efforts to byzantinize the liturgy of the Syriac Melkites and to curb the activity of their ecclesiastical rivals, the Syriac Jacobites, must have gone hand in hand.

Given that Ibrāhīm was a patron of Graeco-Syriac liturgical translations, did he also sponsor some Graeco-Arabic translations produced in Antioch (in addition, of course, to his own translation work)? This seems quite likely. In fact, his Arabic translation of Pseudo-Gregory of Nyssa's Encomium to St. Ephrem is appended to the Arabic version of fifty-two homilies by Ephrem. ${ }^{35}$ Contrary to what some scholars have maintained, Ibrāhīm is not the translator of the collection of fifty-two homilies by Ephrem. ${ }^{36}$ Nonetheless, the fact that the collection concludes with his translation of Pseudo-Gregory of Nyssa's Encomium to St. Ephrem may indicate that he sponsored and/or endorsed it in some way. At the end of some Arabic manuscripts of Pseudo-Gregory of Nyssa's Encomium to St. Ephrem there is a note that states:

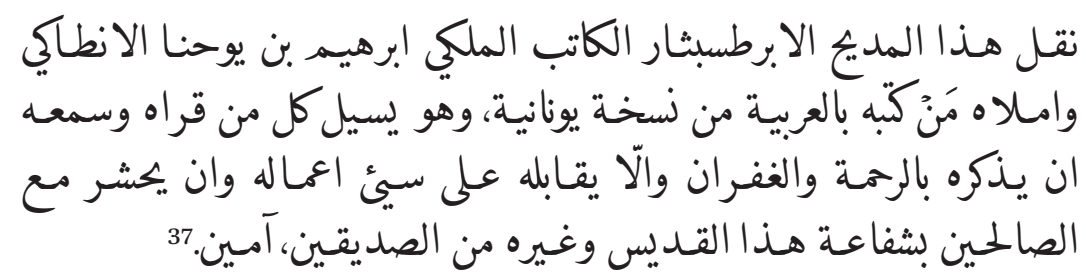

34 Nasrallah, Histoire, vol. III.1, p. 289; Mugler, "Ibrāhīm ibn Yūḥannā," pp. 193-194. On patriarch Alexios' decree, see Gilbert Dagron, "Minorités ethniques et religieuses dans l'Orient byzantin à la fin du $\mathrm{X}^{\mathrm{e}}$ et au XI ${ }^{\mathrm{e}}$ siècle: L'immigration syrienne," Travaux et mémoires 6 (1976): 177-216, at pp. 200-204. On the title "mystikos," see Rodolphe Guilland, "Études sur l'histoire administrative de l'empire byzantin: Le mystique, ó $\mu \nu \sigma \tau$ xós," Revue des études byzantines, 26 (1968): 279-296 (with "Abramios, protospatharios over the God-guarded bedchamber and mystikos" referenced on p. 284).

35 On this collection, see Samir Khalil Samir, "Le Recueil éphrémien arabe des 52 homélies," Orientalia Christiana Periodica 39 (1973): 307-332.

36 The Arabic translation of these fifty-two homilies has a very distinctive style, similar to such works as the Noetic Paradise and the Epistle lectionary of Sinai ar. 169 (and other manuscripts) - notably, the idiosyncratic rendering of $\sigma \alpha \dot{\alpha} \xi \xi$ as bašara, under the influence of the Syriac حمن r. It is therefore quite different from Ibrāhīm's translations. Cf. Alexander Treiger, "The Noetic Paradise (al-Firdaws al-'aqlī): Chapter XxIv," in: Barbara Roggema and Alexander Treiger (eds.), Patristic Literature in Arabic Translations, Leiden: Brill, 2020, pp. 328-376.

37 Paris, BnF ar. 135, fol. 293v. Vat. ar. 463, fol. $184 \mathrm{v}$ has a slightly shorter version of the note: نقـل هـذا المـديه الابرطسبثار الكاتب الملكي ابرهيم بن يوحنا الانطاكي وامـلاه مَنْكَبه 
The protospatharios and imperial secretary Ibrāhīm ibn Yūhannā of Antioch translated this encomium, dictating it from a Greek copy to someone who wrote it in Arabic. [The Arabic copyist] asks whoever will read it or hear it to remember him [in prayer, asking God] to have mercy [on him], forgive [his sins], and not to recompense him for his evil deeds, but that he may be resurrected with the virtuous, through the prayers of this saint [St. Ephrem] and all the righteous ones, Amen.

Though this is far from certain, this note may indicate that the Arabic translator of the fifty-two homilies of Ephrem visited Ibrāhīm the protospatharios, and it was during this visit that Ibrāhīm translated extemporaneously and dictated to him Pseudo-Gregory of Nyssa's Encomium, which was then added to the collection of fifty-two homilies.

\subsection{Gregory, Abbot of the Monastery of the Theotokos Dafnūna}

A recent article by Sergey Kim has summarized the scant information about Gregory of Dafnūnā at our disposal. He has also provided a critical edition and French translation of Gregory's Syro-Arabic version of Pseudo-Severian of Gabala's Homily on Nativity ( $C P G 4290) .{ }^{38}$ There is little that can be added to this description, but it is worth investigating the only other translation known to have been produced by Gregory of Dafnūnā: the Syro-Arabic version of Philoxenos of Mabbug's Letter to Patrikios. ${ }^{39}$ Several manuscripts have the following note at the end of the text:
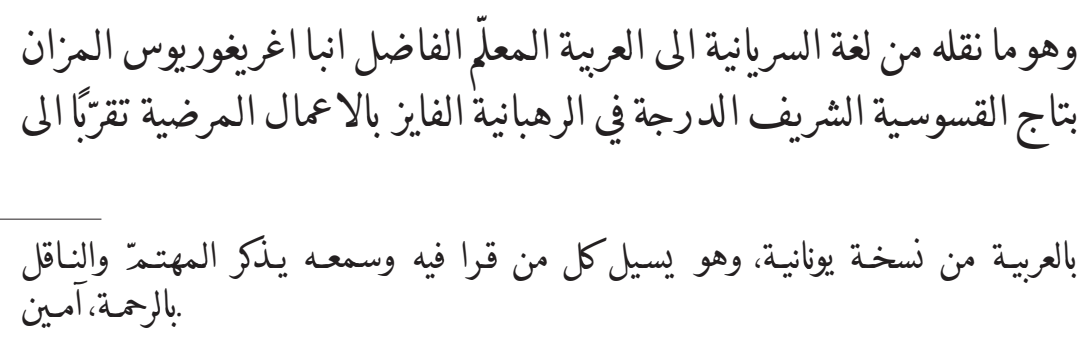

38 Sergey Kim, "L' homélie arabe In Nativitatem Domini (CPG 4290) attribuée à Sévérien de Gabala: Édition, traduction française," in: Barbara Roggema and Alexander Treiger (eds.), Patristic Literature in Arabic Translations, Leiden: Brill, 2020, pp. 276-327.

39 The following seems to be a complete list of manuscripts: Sinai ar. 328 (year 1816), fols. 183r-210v; Sinai ar. $35^{2}$ (13th cent.), fols. 139r-161v; Sinai ar. 444 (year 1218), fols. 288v-305r; Paris, BnF ar. 253 (14th cent.), fols. 219r-233v; Jerusalem, Holy Sepulchre 59 (18th cent.), fols. 107r-139v; Damascus, Orthodox Patriarchate 162 [olim 1606] (year 1827); Damascus, Orthodox Patriarchate 1633 (year 1833), No. 6 [this manuscript cannot be identified at present]; Beirut, Bibliothèque Orientale 481 (year 1871), pp. 120-172; and possibly Šarfé ar. 7/3 (1282), No. 3. Nasrallah, Histoire, vol. III.1, p. 307 mentions also Sinai ar. 362 and Vat. ar. 362 , but these two manuscripts do not contain the text. 


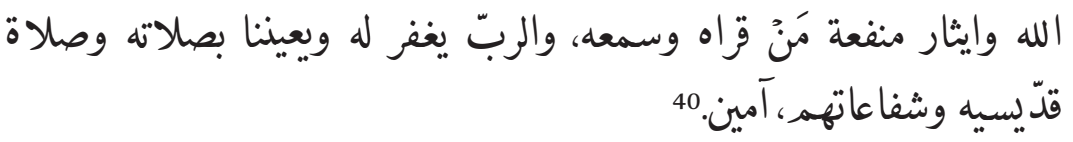

This is what the excellent teacher Abba Gregory, adorned with the crown of priesthood, holding an exalted rank in monasticism, who has earned deeds pleasing [to God], translated from the Syriac language into Arabic in order to draw near God and to bring benefit to whoever will read it and listen to it. May the Lord forgive him [his sins] and assist us by his prayer and by the prayer and intercessions of His saints, Amen.

It is noteworthy that in this note Gregory is not called abbot; he is said to be a priest and a (high-ranking) monk. It is possible, therefore, that this translation was produced before he became abbot. ${ }^{41}$

As is well known, in the Syriac Melkite tradition (Sinai syr. 24 and, probably, Vat. syr. 125) Philoxenos of Mabbug's Letter to Patrikios was re-attributed to a certain "St. Symeon." 42 In the Greek translation of this text produced by the monks Patrikios and Abramios ca. 80o AD at the Monastery of Mar Saba, together with the Greek version of the first volume of Isaac the Syrian, this St. Symeon (further designated as being "of Caesarea" or "the Wonderworker," depending on the manuscript) is not the author but rather the addressee of the text (Isaac the Syrian being the presumed author). ${ }^{43}$ While it has been suggested that it was the Greek translators who made St. Symeon into the addressee of the text, ${ }^{44}$ the situation is complicated by the Syro-Arabic version under discussion, which very clearly identifies Isaac the Syrian as the author and St. Symeon (designated "the Stylite") as the addressee.

$40 \quad$ Sinai ar. 444 , fol. 3 o5r.

41 Whatever the case might be, there is no doubt that the translator of Philoxenos of Mabbug's Letter to Patrikios and of Pseudo-Severian of Gabala's Homily on Nativity is one and the same person.

42 Grigory Kessel, "Sinai syr. 24 as an Important Witness to the Reception History of Some Syriac Ascetic Texts," in: Françoise Briquel-Chatonnet and Muriel Debié (eds.), Sur les pas des Araméens chrétiens: Mélanges offerts à Alain Desreumaux, Paris: Geuthner, 2010, pp. 207-218 (on Sinai syr. 24 and its membra disiecta, see Géhin, Les manuscrits syriaques, pp. 67-68); Алексей В. Муравьев, “«Послание к авве Симеону» в сборнике 'Абхүтюоі

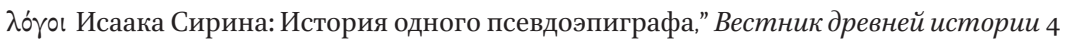
(2012): 49-62.

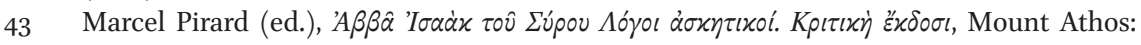
Iveron Monastery, 2012, pp. 825-861.

44 Kessel, "Sinai syr. 24," p. 216. 
I am presenting below the beginning of the text in both Syriac (Sinai syr. 24) and Arabic (Sinai ar. 444). As will be obvious, with the exception of the different caption, the Arabic is an extremely faithful, almost word-for-word translation of the Syriac, which was apparently made with no reference to the Greek. The Arabic translation, therefore, sheds further light on the Syriac Melkite transmission history of this text. It allows us to hypothesize that the original Syriac Melkite manuscript from which the Greek translation was produced may have likewise designated St. Symeon as the addressee. As such, the Arabic translation deserves a careful study.

Sinai syr. 24, fols. $147 \mathrm{~V}-148 \mathrm{r}$

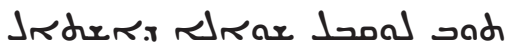

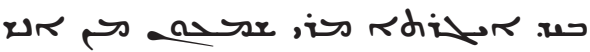

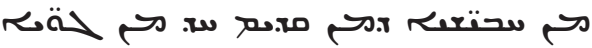

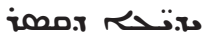

Sinai ar. 444 , fol. $288 v$

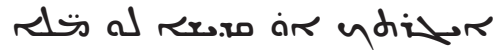

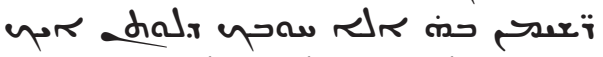

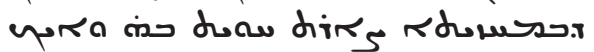
ז

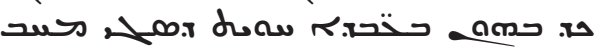
rdara זישם

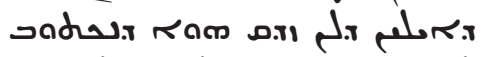


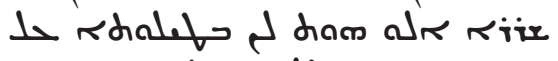

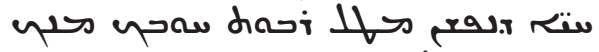

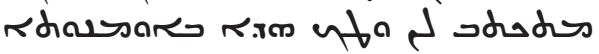
x

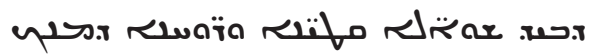

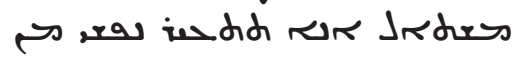

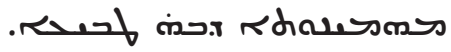

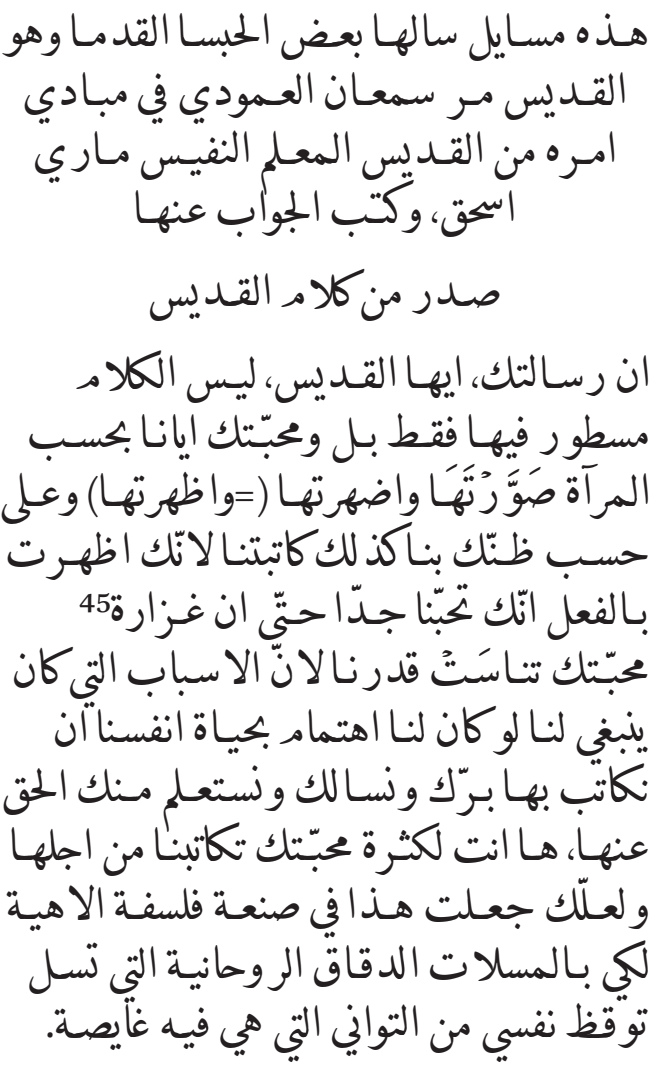

45 MS: عزاة, with the letter $\jmath$ written underneath. 
Again concerning the question which St. Symeon was asked by one of the hermits, who had previously been one of Caesar's well-known eunuchs
These are questions which one of the ancient hermits, St. Symeon the Stylite, at the beginning of his career asked the holy and excellent teacher St. Isaac, and the latter wrote a response to them

\section{The preface of the saint's discourse}

In your letter, $\mathrm{O}$ saint, it is not words that are recorded, but as in a mirror you have depicted and revealed in it your love to us. In accordance with what you think of us, so have you written to us, for you have revealed by these deeds that you love us exceedingly, so much so that because of the abundance of your love you forgot our [lowly] measure. Indeed, concerning those [matters] about which we should have written to you and asked your piety, if we had concern for the life of our souls, so as to learn from you the truth, [this] is being written to us by you, on account of the greatness of your love. You have probably done this with a skill in divine philosophy, so that, by means of the subtle and spiritual questions that I am being asked by you, my soul may be awakened from the negligence in which it is immersed.
In your letter, $\mathrm{O}$ saint, it is not only words that are recorded, but as in a mirror you have depicted and revealed your love to us. In accordance with your view of us, so have you written to us, for you have revealed in action that you love us exceedingly, so much so that the abundance of your love forgot our [lowly] measure. Indeed, concerning the matters about which we should have written to you and asked your piety, if we had concern for the life of our souls, so as to learn from you the truth about them, you are herewith writing to us, on account of the greatness of your love. You have probably done this with a skill in divine philosophy, so that, by means of the subtle spiritual questions that you ask [me], my soul may be awakened from the negligence in which it is immersed.

One last point about Gregory of Dafnūnā: his Syro-Arabic translation activity correlates well with Abba Abraham's Syro-Arabic revision of the Arabic translation of John Climacus' Book of the Ladder (this revision had been done in the 930s, i.e., some two-three generations before Gregory), discussed in section 1.2 above. As already mentioned, Abba Abraham had been active at that same Monastery of the Theotokos Dafnūnā. We can presume that this monastery had a continuous tradition of translating Syriac works into Arabic both before and after the Byzantine re-conquest. 


\subsection{Chariton, Abbot of the Monastery of the Theotokos Aršāya}

As we learn from a recently edited colophon, the Monastery of the Theotokos Aršãyā was located "west of the city of Antioch, outside the gate known as Bāb al-Fuḍayl” ('̇arbìmadīnat Anțākiya zāhir al-bāb al-ma' rūf bi-Bāb al-Fudayl). ${ }^{46}$

Although Chariton of Aršayana is absent from the list of Christopher's disciples in Ibrāhīm the protospatharios' Life of Christopher, as preserved in the manuscripts, the text happens to be corrupt at precisely this point, and there are, I believe, some signs that Chariton of Aršāâa's name may have originally been there. The Arabic text reads as follows:

ed. Zayat, p. 364

ومنهـم انبا خـاريطن الثاني

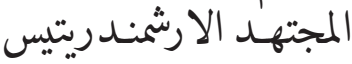

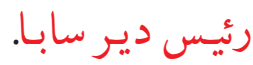

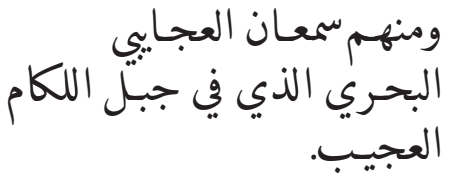

Sinai ar. 405, fol. $131 \mathrm{r}$

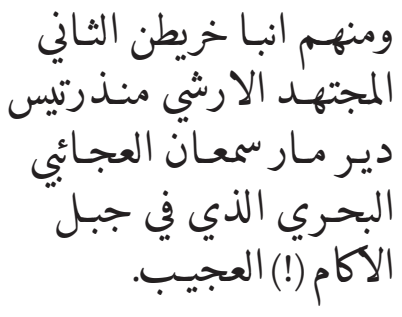

Reconstruction (hypothetical)

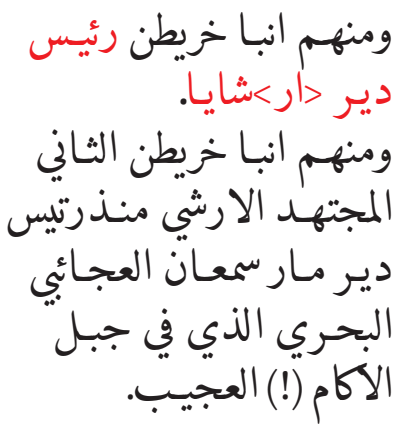

Among them: Abba Chariton, the abbot of the monastery of < Ar>šāyā.
Among them: the second Abba Chariton, the industrious, the
Among them: the second Abba Chariton, the industrious, the

46 This information is preserved in the colophon of Sinai ar. 398, fol. $310 v$ (this manuscript was collated at the Monastery of the Theotokos Aršāyā); cf. Alexander Treiger, "Sinaitica (1): The Antiochian Menologion, Compiled by Hieromonk Yūḥannā 'Abd al-Masīḥ (First Half of the 13th Century)," Christian Orient / Христіанскій Востокъ 8 (14) (2017): 215-252, at pp. 218-219. On the monastery of the Theotokos Arshāyā, see Nasrallah, Histoire, vol. III.1, pp. 308-309; Todt and Vest, Syria, vol. 1, pp. 419, 615, and $65^{2}$ (on the last two occasions misnamed, based on a copyist's mistake in Yahyā al-Anțākī's history, "the monastery of St. Arsenios"; the same mistake in Gérard Troupeau, "Les Églises d'Antioche chez les auteurs arabes," in: Floréal Sanagustin (ed.), L'Orient au cœur: En l'honneur d'André Miquel, Paris: Maisonneuve \& Larose, 2001, pp. 319-327, esp. 326). Two Sinai manuscripts were copied at the Monastery of the Theotokos Aršāyā: Sinai ar. 63/Part I (late 12th century, copyist: monk Macarius/Makārī) and Sinai ar. 356/Part I (year 1185; copyist: reader Meletius/Malātī); both of them were commissioned by monk Sābā at Sinai. Sinai ar. 326 (year 1244) was copied by Ğuwān ibn Dimitrī <ibn Yūḥannā> ibn Ḥamza for the deacon Abba Barnabas/Farnāfā al-Ițrablusī from the monastery of the Theotokos Aršāyā; cf. Treiger, "Sinaitica (1)," pp. 220-221. The gate Bāb al-Fuḍayl is otherwise unattested. 
archimandrite, the abbot of the Monastery of Saba. Among them: Symeon the Wonderworker by the sea, on the Wondrous Black Mountain. archimandrite of the Monastery of St. Symeon the Wonderworker by the sea, on the Wondrous Black Mountain.
Among them: the second Abba Chariton, the industrious, the archimandrite of the Monastery of St. Symeon the Wonderworker by the sea, on the Wondrous Black Mountain.

In his article "Deux auteurs melchites inconnus du $\mathrm{x}^{\mathrm{e}}$ siècle," Joseph Nasrallah has rightly criticized the grave errors (les graves erreurs) of Zayat's edition caused by the defective state (l'etat defectueux) of the underlying manuscript (the manuscript, unfortunately, cannot be identified). Clearly, Zayat's reading is untenable because, as pointed out by Nasrallah, it makes of the sixth-century saint Symeon the Stylite the Younger into yet another disciple of the martyred patriarch Christopher!47 The reading of the Sinai manuscript, by contrast, is clearly superior, because it does not contain such incongruities.

Nonetheless, questions remain. What is striking about the text as preserved in both manuscripts is that they mention "the second Abba Chariton" without any reference to the first Abba Chariton. It is, of course, quite possible that there had been another (unmentioned) abbot of the same monastery whose name had also been Chariton, and it is for this reason that this new Chariton was dubbed "the second." 48 Still, it is rather uncharacteristic of medieval Christian Arabic texts to mention an abbot (or, for that matter, a patriarch or a bishop) with the sequential numeral, for the simple reason that historical memory would have been rather short at the time, and authors and copyists would not have been in a position to know how many similarly-named predecessors the current holder of an ecclesiastical office would have had.

It is much easier to assume that Ibrāhīm the protospatharios' text had originally mentioned the first Abba Chariton, but that the clause in question happened to fall out due to a copyist's mistake (homoioarchton: i.e., the copyist's eye would have skipped from one paragraph to the next, because both of them began with ومنf). If this hypothesis is correct, then the first Abba Chariton

47 Joseph Nasrallah, "Deux auteurs melchites inconnus du $\mathrm{x}^{\mathrm{e}}$ siècle," Oriens Christianus 63 (1979): 75-86, at pp. 8o-81, n. 23; cf. Habib Zayat, "Vie du patriarche melkite d'Antioche Christophore $(\dagger 967)$ par le protospathaire Ibrahim b. Yuhanna: Document inédit du $\mathrm{x}^{\mathrm{e}}$ siècle," Proche-Orient chrétien, 2 (1952): 11-38 and 333-366, at pp. 364-365. 
would have been Chariton, the abbot of the Monastery of the Theotokos Aršãyā near Antioch, who is attested as a Graeco-Arabic translator (see below).

This, incidentally, helps us explain the presence of an intriguing element in Zayat's text: according to Zayat's transcription, (the second) Abba Chariton was "the abbot of the Monastery of Saba." Nasrallah has criticized this reading on the ground that such a monastery is "unknown in northern Syria" (inconnu dans la Syrie du Nord $).{ }^{49}$ While he is certainly correct in rejecting this reading, he has not explained how it arose in the first place. The hypothesis presented above, if accepted, would allow us to explain how this happened. The erroneous variant "the Monastery of Saba" (دير سابـ) would have arisen from "the Monastery of <Ar>šāyā" (دير خار(شايا). In the original text, "the Monastery of $<$ Ar>šãyā" would have served as an indication for the location of "the first Abba Chariton." Of course, it must be stressed that the proposed reconstruction is hypothetical; it is to be hoped that additional manuscripts of the Life of Christopher will be discovered, which will help verify (or refute) it. ${ }^{50}$

Be it as it may, it is, I believe, quite possible that Chariton of Aršãyā was a disciple of the martyred patriarch Christopher. His only translation known to us is the Arabic version of select homilies from Theodore the Studite's Little Catechesis. ${ }^{51}$ It is striking that there are no studies of this translation. Below I

49 Nasrallah, "Deux auteurs melchites," pp. 8o-81, n. 23.

50 One manuscript that ought to be checked is the newly discovered Saint Petersburg manuscript of the Antiochene Menologion, discussed at the end of Section 4 below (and n. 67 there). It may very well contain another copy of the Life of Christopher in its May volume.

For a provisional list of manuscripts, see Nasrallah, Histoire, vol. III.1, pp. 308-310. To these manuscripts, the following can be added: Sinai ar. 49o, fols. $1 \mathrm{r}-136 \mathrm{v}$ (breaks off in the middle of $55^{\text {th }}$ ' $i z a$ due to loss of folios); Sinai ar. 491; Sinai ar. NF Paper $30+50$ (two parts of the same manuscript, copied apparently by the Sinaitic copyist Nilus al-Dimašqī). By contrast, Nasrallah's reference to "Sin. $\operatorname{ar} .567$ (XIII ${ }^{\mathrm{e}}$ s.) ff. $99^{\mathrm{v}}-107^{\mathrm{v}}$ " is mistaken. His references

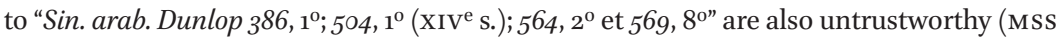
386 and 569 in Margaret Dunlop Gibson's catalogue do not correspond to the current Sinai ar. 386 and Sinai ar. 569, both of which contain Nikon's Pandectes; Sinai ar. 504 contains homilies of Theodore Abū Qurra on the fourth and fifth Sunday of Lent [cf. Jerusalem, Mār Ya'qūb 8, which may have been copied from this manuscript], but nothing by Theodore the Studite; MS 564 in Gibson's catalogue may not correspond to the current Sinai ar. 564, though this requires further investigation; moreover, all of Gisbon's references mention only "Theodore" without specification). There is also an intriguing text ascribed to Theodore the Studite in Sinai ar. 451, fol. 96r-104r (?): hāda ma ma rasamahu al-ab

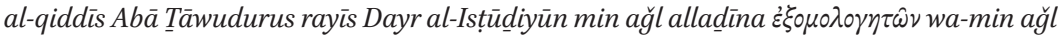
alladina $\delta ı \delta a \sigma x \alpha \dot{\lambda} \omega \nu$ (the text leaves multiple terms in Greek script untranslated). 
present the beginning of the text in both Greek and Arabic, in the hope that this will encourage further investigation.

Emmanuel Auvray (ed.), Sancti patris nostri et confessoris Theodori Studitis prcepositi Parva catechesis, Paris: Victor Lecoffre, 1891, pp. 1-2

\section{TOY OГIOY ПATPO $\mathrm{HM} \Omega$ N KAI ОМО $\Lambda$ ОНТОY $\Theta E O \Delta \Omega P O Y$ HГOYMENOYTSN $\Sigma$ TOY $\triangle$ IOY ... KATHXH $\Sigma I \Sigma$ A' $^{\prime}$ ПEPI TOY ENAT $\Omega N I \Omega \Sigma$ $\triangle I A N Y E I N T O N$ OAON HMSN BION}

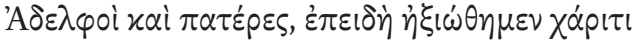

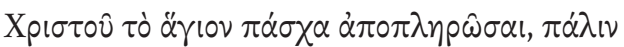

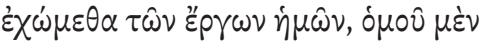

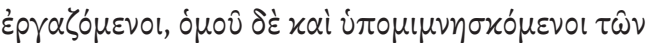

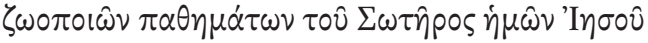

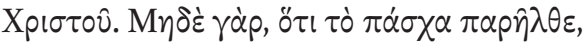

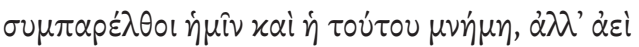

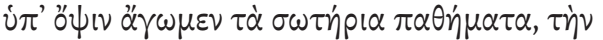
$\sigma \tau \alpha \nu \dot{\rho} \omega \sigma \tau, \tau \dot{\eta} \nu \tau \alpha \varphi \dot{\eta} \nu, \tau \dot{\eta} \nu \alpha \dot{\alpha} \alpha \dot{\alpha} \sigma \alpha \alpha \omega \nu, o ̈ \pi \omega \varsigma \tau \hat{\eta}$

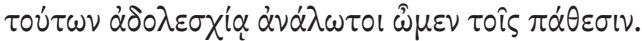

Sinai ar. 326, fol. 1r-v (illegible at times); Sinai ar. 593, fol. $89 \mathrm{v}$ 
In the list of Christopher's disciples appended to the Life of Christopher, Ibrāhīm mentions a certain "Abba Yūhannā the marvelous, who was deemed worthy to become catholicos over the land of the east (anbā Yüḥannā al-'ağíb allad̄i uhhila li-an șāra qātūilìqan 'alā balad al-mašriq)." ${ }^{" 6}$ The specification "over the land of the east" indicates that Yūhannā was the catholicos of Romagyris (not the catholicos of Baghdad). ${ }^{57}$

Joseph Nasrallah conjectures that "Yūḥannā the marvelous" is identical with "John the catholicos" mentioned by the eleventh-century Antiochene Greek author Nikon of the Black Mountain in chapter 26 of the Taktikon..$^{58}$ As we shall see below, Nasrallah's identification is correct. It is therefore crucial to consider the relevant passage. Nikon writes:

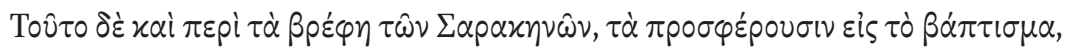

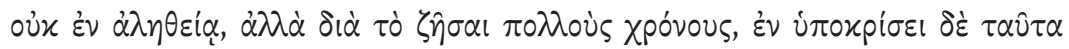

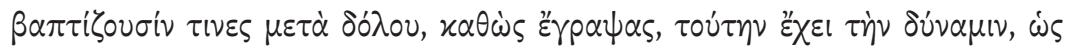

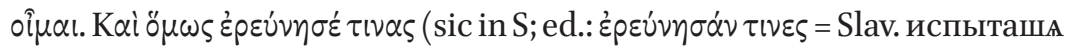

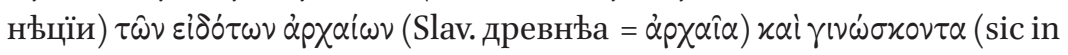

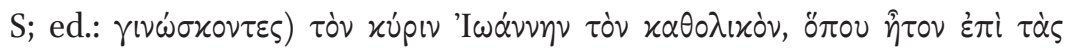

$56 \quad$ Nasrallah, "Deux auteurs melchites," pp. 79-8o.

57 On the Melkite catholicosates in Baghdad and Romagyris see Wassilios Klein, "Das orthodoxe Katholikat von Romagyris in Zentralasien," Parole d'Orient 24 (1999): 235-265; Jean-Maurice Fiey, "Rum à l'est de l'Euphrate," Le Muséon 90 (1977): 365-420; Joseph Nasrallah, "Réponse à quelques critiques récentes au sujet des catholicosats melchites de Bagdad et de Romagyris," Proche-Orient Chrétien 33 (1983): 160-17o; Joseph Nasrallah, "L'Église melchite en Iraq, en Perse, et dans l'Asie centrale," Proche-Orient Chrétien 25 (1975): 135-179; 26 (1976): 16-33; 27 (1977): 71-78, 277-293; Jean Dauvillier, "Byzantins d'Asie Centrale et d'Extrême-Orient au moyen âge," Revue des Études Byzantines 11 (1953): 62-87; Neophytos Edelby, "Note sur le catholicosat de Romagyris," Proche-Orient Chrétien 2 (1952): 39-46; Ken Parry, "Byzantine-Rite Christians (Melkites) in Central Asia in Late Antiquity and the Middle Ages," in: Elizabeth Kefallinos (ed.), Thinking Diversely: Hellenism and the Challenge of Globalisation (special edition of Modern Greek Studies (Australia and New Zealand), 2012), pp. 91-108; Ken Parry, "Byzantine-Rite Christians (Melkites) in Central Asia and China and Their Contacts with the Church of the East," in: Li Tang and Dietmar W. Winkler (eds.), Winds of Jingjiao: Studies on Syriac Christianity in China and Central Asia, Zurich: Lit Verlag, 2016, pp. 203-22o; Krzysztof Kościelniak, "The Melkites - 'People of the Emperor' in Abbasid Baghdad and Central Asia," in: Krzysztof Kościelniak (ed.), Prosperity and Stagnation: Some Cultural and Social Aspects of the Abbasid Period (7501258), Krakow: UnUm Publishing House, 2010, pp. 101-114.

58 Nasrallah, "Deux auteurs melchites inconnus," p. 80, n. 22; Nasrallah, Histoire, vol. III.1, p. 303, n. 277; with reference to Joseph Nasrallah, "L'Église melchite en Iraq, en Perse et dans l'Asie centrale," Proche-Orient chrétien 26 (1976): 319-353, at p. 322. 


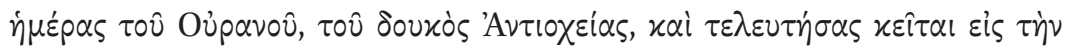

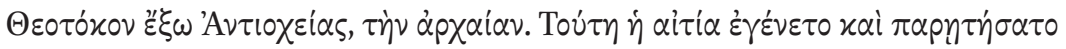

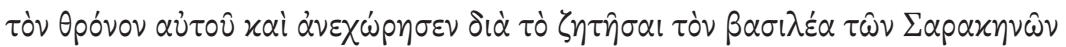

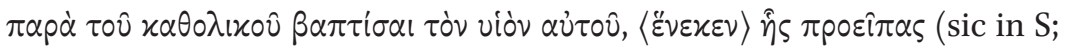

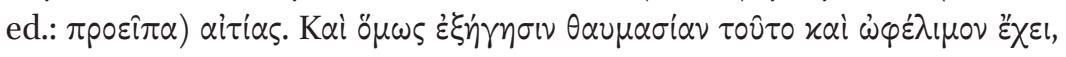

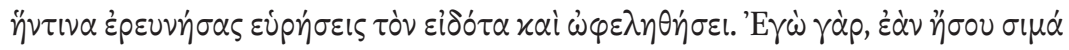

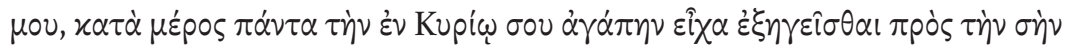
xai $\alpha \lambda \lambda \omega \nu \omega \dot{\omega} \varphi \dot{\varepsilon} \lambda \varepsilon i \alpha \nu .{ }^{59}$

[Regarding your question] about the infants of the Saracens - that "they bring them to baptism not with the true [intention], but so that they may live for many years, and some [priests] baptize them hypocritically and fraudulently," as you have written - this [baptism] is valid, in my opinion. However, you should inquire with some of those who have knowledge of ancient things and know the lord John the catholicos, who lived in the days of Ouranos, the duke of Antioch [=Nicephoros Ouranos, r. 999-ca. 1010], and who after his death lies buried in [the Monastery of] the Theotokos, [called] "the old one" [=Aršãyā]. This was the reason why he rejected his throne and retired: the king of the Saracens had asked that his son be baptized by the catholicos for precisely the reason you indicated above. There is an amazing and beneficial account [of John the catholicos' affair]. If you inquire about it, you will find someone who knows it, and you will benefit [from it]. If you were near me, I would have recounted to your person so beloved in the Lord everything in detail for your own and others' benefit.

Nikon of the Black Mountain, Taktikon, chapter 26, §12 - see Christian Hannick et al. (eds.), Das Taktikon des Nikon vom Schwarzen Berge: griechischer Text und kirchenslavische Übersetzung des 14. Jahrhunderts, 2 vols., Freiburg im Breisgau: Weiher, 2014, vol. 2, p. 718 (cf. Sinai gr. 441, fol. 194r-v: <https://www.loc.gov/resource/amedmonastery.0027938149A$\mathrm{ms} /$ ?sp=196>; the editors misunderstand the text as referring to one of the Georgian catholicoi). For an Arabic translation, see Sinai ar. 385, fol. 243r:فاّا سوالك عن اطفال

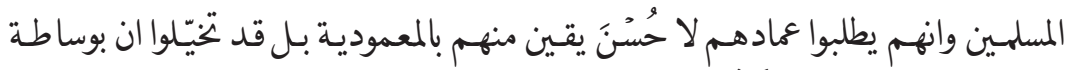

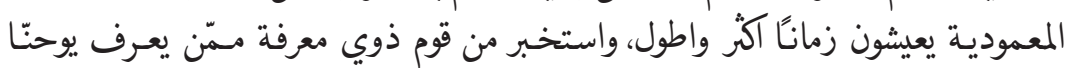

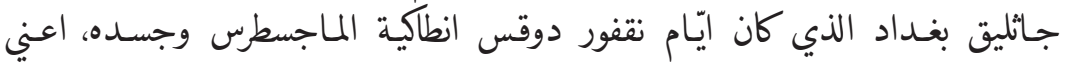

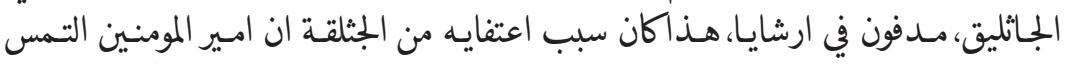

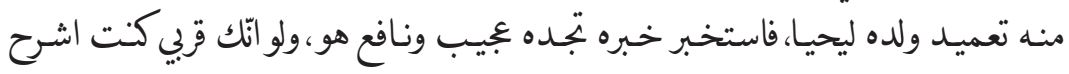

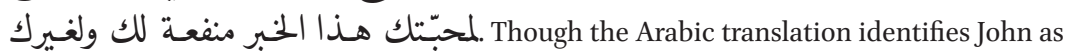
the catholicos of Baghdad rather than Romagyris, this has no support in the Greek text and seems to be an erroneous conjecture by the Arabic translator. 
Another relevant source is the Antiochene Menologion - a multi-volume collection of festal homilies and lives of saints for the entire liturgical year. As I have demonstrated in my 2017 article on the Antiochene Menologion, its compiler was a certain Yūḥannā 'Abd al-Masīḥ. Crucially, Yūḥannā 'Abd alMasī refers to himself as "priest and monk" (al-qiss wa-l-rāhib), but also mentions several times that he was "elected to be catholicos" (al-muhtār li-l-ğatllaqa, or simply al-muhtār). On one occasion he specifies that he was "elected to be catholicos of Romagyris and Šāš" (al-muhtāar qātūulīq li-Rūmağird wa-Šāš). Since, however, Yūḥannā 'Abd al-Masīh continued to refer to himself as "priest and monk" even after his election, my conclusion was that he "rejected the appointment, preferring monastic life and scholarly work as a translator and a compiler to episcopal dignity."60 In that same article, I also noted that the oldest copy of the Antiochene Menologion (Sinai ar. 398, 401, 403, 406, and 408, copied in 1258-1259) was collated with Yūhannā 'Abd al-Masīḥ's autograph, which was then kept at the Monastery of the Theotokos Aršãà near Antioch. I therefore hypothesized that Yūḥannā 'Abd al-Masịh could have been a monk at that monastery. ${ }^{61}$

There is hardly any doubt that Nikon's "John the catholicos" and Yūhannā 'Abd al-Masin (the compiler of the Antiochene Menologion) are one and the same person. It is simply inconceivable that there would have been in relatively close succession two catholicoi both of whom were named Yūhannā, both of whom rejected the appointment, and both of whom had some connection to the Monastery of the Theotokos Aršāyā. Indeed, Nikon's account constitutes the missing piece of the puzzle, which complements the information provided by Yūḥannā 'Abd al-Masīh about himself. Specifically, it explains why Yūḥannā 'Abd al-Masīh mentions that he was "elected to be catholicos" but continues to refer to himself as "monk and priest." The reason for this is - as Nikon explains - that "John the catholicos" (=Yūḥannā 'Abd al-Masịh ) refused to baptize a Muslim ruler's child (because this baptism was not sought for the right reasons) and was therefore forced to abdicate. Upon his abdication - as we also learn from Nikon - "John the catholicos" (=Yūḥannā 'Abd al-Masīḥ) returned to Antioch. He must have retired to the Monastery of the Theotokos Aršãyā and was buried in that monastery. The autograph of his magnum opus - the Antiochene Menologion - would have consequently remained at the Monastery of the Theotokos Aršāyā, where it was used in the mid-thirteenth century to correct a freshly penned copy of the Antiochene Menologion commissioned by Mount Sinai.

\footnotetext{
6o Treiger, "Sinaitica (1)," p. 233.

$61 \quad$ Treiger, "Sinaitica (1)," pp. 219-221.
} 
It should be noted that in that same article I dated Yūhannā 'Abd al-Masīh to the first half of the thirteenth century. This dating was based on a nineteenth-century catalogue entry for the manuscript formerly known as "Sinai Porph. 228," reportedly copied by Yūhannā 'Abd al-Masīh in the year 6752 to the Creation, i.e., $1243 / 4 \mathrm{AD}{ }^{62}$ The problem is that this manuscript cannot be identified; in fact, it may no longer be extant. Thus, it is impossible to control this information. It is certainly imaginable that there could be a slight mistake in the catalogue: for example, that though the manuscript in question was indeed copied in 1243/4 AD, Yūhannā 'Abd al-Masīh was not the copyist, but the translator of the text(s) contained therein. In that case, Yūhannā 'Abd al-Masịh would have to be dated to before $1243 / 4 \mathrm{AD}$. Alternatively, this manuscript could have reproduced its antigraph's colophon. In short, my thirteenth-century dating of Yūḥannā 'Abd al-Masīh rested on rather shaky ground.

Habib Ibrahim, who published an extensive analysis of the Antiochene Menologion, has rightly criticized the thirteenth-century dating of Yūhannā 'Abd al-Masīḥ. He points out that one of Yūḥannā 'Abd al-Masīḥ's notes implies that he was a contemporary of Ibrāhim the protospatharios (ca. 950-ca. 1030). The note in question appears at the end of Ibrāhīm's translation of Gregory of Nazianzus' Oration 43, a text incorporated into the Antiochene Menologion. It reads:

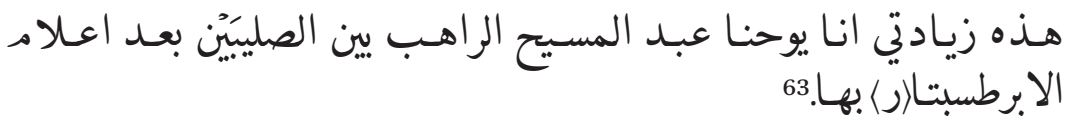

This is my addition between the two crosses - I, Yūḥannā 'Abd al-Masịh the monk - [which I made] after informing the protospatharios about it (ba'd ilām al-ubruțusbatāer $>$ bihā) .

I believe Habib Ibrahim's argument is compelling, and we therefore have no choice but to conclude that Yūḥannā 'Abd al-Masịh was a contemporary and

62 Treiger, "Sinaitica (1)," pp. 236 and 238.

63 Sinai ar. 400, fol. 38 r; Sinai ar. 401, fol. 5or. See Habib Ibrahim, "Liste des vies de saints et des homélies conservées dans les ms. Sinaï arabe 395-403, 405-407, 409 et 423," Chronos 38 (2018): 47-114, at p. 48, n. 2: "Certaines notes du compilateur [Yūḥannā 'Abd al-Masīh]], هذه زيادني انا يوحنا عبد d'ailleurs relevées par Treiger, doivent être mieux étudiées, e.g اعلا مد à cet endroit signifie 'infomer', cela pourrait dire que Yūḥannā 'Abd al-Masīh est un contemporain de Yūḥannā le protospathaire (1oe-11e siècle)." On this note, cf. Jacques Grand'Henry, "Répertoire des manuscrits de la version arabe de Grégoire de Nazianze. Première partie:Égypte," Le Muséon 97.3-4 (1984): 221-253, at pp. 228 and 232. 
acquaintance of Ibrāhīm the protospatharios. As he did not wish to tamper with Ibrāhīm the protospatharios' translation without consulting him first, he informed him that he would make a small addition to the text.

If Yūḥannā 'Abd al-Masīh was a contemporary and acquaintance of Ibrāhīm the protospatharios, we should also conclude that when Ibrāhīm refers to "Abba Yūhannā the marvelous, who was deemed worthy to become catholicos over the land of the east," his reference is to our Yūḥannā 'Abd al-Masīh, who, as we have seen above, is identical to "John the catholicos" mentioned by Nikon of the Black Mountain. Consequently, Ibrāhīm's "Yūḥannā the marvelous," Nikon's "John the catholicos," and Yūhannā 'Abd al-Masị (the compiler of the Antiochene Menologion) must be one and the same person.

We are speaking therefore of someone who was a disciple of the martyred patriarch of Antioch Christopher (d. 967) and was thus born ca. 950. His death date, assuming he lived to an old age, would have to be placed perhaps somewhere in the 103os. He would have thus been a precise contemporary of Ibrāhīm the protospatharios. During Nicephoros Ouranos' rule as duke of Antioch (r. 999-ca. 1010), he would have been appointed as catholicos of Romagyris, but quickly abdicated and returned to Antioch. For Nikon writing in the last third of the eleventh century, "John the catholicos" (=Yūḥannā 'Abd al-Masīh) must have been still in recent memory. ${ }^{64}$

One small problem, however, remains. The Antiochene Menologion compiled by Yūhannā 'Abd al-Masīḥ, who has now been re-dated to ca. 950ca. 103os, includes Michael al-Sim'ānīs Life of St. John of Damascus written shortly after $1085{ }^{65}$ This, however, is not an insurmountable difficulty. We should simply conclude that in the late eleventh century the Antiochene Menologion was "updated" with a more recent entry (and perhaps others as well). ${ }^{66}$ The fact that Michael al-Sim'āni was unable to find a prior vita of John of Damascus may, in fact, be interpreted as meaning that the Antiochene Menologion lacked this vita in its original form. It could have been Michael al-Sim‘ānī

64 Nikon's Taktikon seems to have been compiled ca. $1100 \mathrm{AD}$, but of course the individual letters contained therein would have been penned earlier.

65 Alexander Treiger, "Michael al-Sim`ānī, The Arabic Vita of St. John of Damascus," in: David Thomas et al. (eds.), Christian-Muslim Relations: A Bibliographical History, vol. 5, Leiden: Brill, 2013, pp. 655-664. To the manuscripts listed there one can add: Sinai ar. 423 (year 1623), fols. 238r-247v (this is a one-volume abridgment of the Antiochene Menologion); Sinai ar. 482, fols. 69r-82r; Balamand 153 (16th or 17 th cent.), No. 12. Michael al-Sim'ānīs Life of St. John of Damascus is preserved in two manuscripts of the Antiochene Menologion: Sinai ar. 398 and Sinai ar. 423.

66 This process of "updating" continued later on. Thus, the Sinai copy of the Antiochene Menologion was complemented with the lives of Eudocia and Moses the Abyssinian - see Treiger, "Sinaitica (1)," p. 221, n. 29 and p. 227. 
himself who supplemented the Antiochene Menologion with the missing piece. The resulting manuscripts of the Antiochene Menologion therefore contain it.

It may be useful to mention here that I have been fortunate to identify another, reportedly complete extant copy of the Antiochene Menologion. This is Saint Petersburg, National Library of Russia, Arab. N.S. 92, vols. I-VIII (brought to Saint Petersburg as part of Porphyry Uspensky's collection). It was copied in 1845 by Ḥannā ibn Ğirğis Ṣarrūf al-Dimašqi. Though relatively late, this manuscript (probably copied from an antigraph then kept at the Orthodox Patriarchate in Damascus, but subsequently destroyed in the 1860 riots) may provide additional valuable information about the Antiochene Menologion and its compiler Yūḥannā 'Abd al-Masịh. This monumental work certainly requires further study. ${ }^{67}$

To conclude: the Melkite Graeco-Syro-Arabic translation movement in Antioch was a highly significant cultural undertaking. Though its roots go back to the early ninth century, when the first translation (from Greek into Syriac) attributable to Antioch was produced, it gained momentum after the Byzantine re-conquest of Antioch in 969. As demonstrated above, in the late tenth and early eleventh century, the Antiochene translation movement was spearheaded by four translators, all of them disciples of the patriarch Christopher: Ibrāhīm the protospatharios, Gregory of Dafnūnā, Chariton of Aršāyā (if my reconstruction of Ibrāhīm the protospatharios' reference is correct), and, finally, Yūhannā 'Abd al-Masīh, the author of the Antiochene Menologion (herewith re-dated to the early eleventh century). Their Arabic translations - and those of their immediate successors, Antonios and 'Abdallāh ibn al-Faḍl - deserve the closest attention of all those interested in the Greek Church Fathers, the transmission of their works in both Greek and Arabic, and the profound influence they exerted upon Arabic-speaking Christians of the Middle East.

$67 \quad$ I am deeply grateful to Boris Zajkovskij of the National Library of Russia for confirming the call number of this important manuscript (personal communication, August 16, 2019). I intend to consult this manuscript during a future visit to Saint Petersburg. 